\title{
A comparative study of fuzzy logic-based models for groundwater quality evaluation based on irrigation indices
}

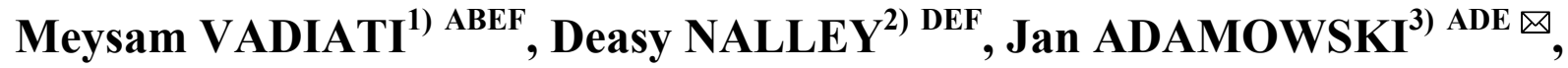 \\ Mohammad NAKHAEI ${ }^{4)}$ CE , Asghar ASGHARI-MOGHADDAM ${ }^{\text {() AEF }}$
}

1) orcid.org/0000-0003-0841-6919; Kharazmi University, Department of Applied Geology, Faculty of Earth Sciences, Tehran, Iran; McGill University, Department of Bioresource Engineering, Faculty of Agricultural and Environmental Sciences, Quebec, Canada; e-mail: Mey_vadiati@tabrizu.ac.ir

2) orcid.org/0000-0003-3714-6110; McGill University, Department of Bioresource Engineering, Faculty of Agricultural and Environmental Sciences, Quebec, Canada; e-mail: deasynalley.mcgill@gmail.com

3) orcid.org/0000-0002-1242-3364; McGill University, Department of Bioresource Engineering, Faculty of Agricultural and Environmental Sciences, Quebec, Canada; e-mail: jan.adamowski@mcgill.ca

4) orcid.org/0000-0002-4823-5197; Kharazmi University, Department of Applied Geology, Faculty of Earth Sciences, Tehran, Iran; e-mail: nakhaei@khu.ac.ir

5) orcid.org/0000-0002-5984-094X; University of Tabriz, Department of Earth Sciences, Faculty of Natural Science, Tabriz, Iran; e-mail:moghaddam@tabrizu.ac.ir

For citation: Vadiati M., Nalley D., Adamowski J., Nakhaei M., Asghari-Moghaddam A. 2019. A comparative study of fuzzy logicbased models for groundwater quality evaluation based on irrigation indices. Journal of Water and Land Development. No. 43 (X-XII) p. 158-170. DOI: 10.2478/jwld-2019-0074.

\begin{abstract}
Groundwater quality modelling plays an important role in water resources management decision making processes. Accordingly, models must be developed to account for the uncertainty inherent in the modelling process, from the sample measurement stage through to the data interpretation stages. Artificial intelligence models, particularly fuzzy inference systems (FIS), have been shown to be effective in groundwater quality evaluation for complex aquifers. In the current study, fuzzy set theory is applied to groundwater-quality related decision-making in an agricultural production context; the Mamdani, Sugeno, and Larsen fuzzy logic-based models (MFL, SFL, and LFL, respectively) are used to develop a series of new, generalized, rule-based fuzzy models for water quality evaluation using widely accepted irrigation indices and hydrological data from the Sarab Plain, Iran. Rather than drawing upon physiochemical groundwater quality parameters, the present research employs widely accepted agricultural indices (e.g., irrigation criteria) when developing the MFL, SFL and LFL groundwater quality models. These newly-developed models, generated significantly more consistent results than the United States Soil Laboratory (USSL) diagram, addressed the inherent uncertainty in threshold data, and were effective in assessing groundwater quality for agricultural uses. The SFL model is recommended as it outperforms both MFL and LFL in terms of accuracy when assessing groundwater quality using irrigation indices.
\end{abstract}

Key words: fuzzy inference model, fuzzy rules, irrigation indices, Larson model, Mamdani model, Sugeno model, Sarab Plain

\section{INTRODUCTION}

The potable, domestic, industrial and agricultural use of water resources has contributed to global concerns regarding the degradation of water quality [VADIATI et al. 2018]. The main causes of water quality issues include agricultural practices, expanding industries and tourism [GOETHALS, VOLK 2016]. Groundwater quality deterioration, and its effects on soil quality and farmland productivity, is also problematic. In semi-arid countries particularly, population growth and rising water demands have led to the over-exploitation of surface and ground water re- 
sources. This rising pressure on water resources has increased the need for groundwater quality assessments [BAIN et al. 2014]. In the Middle East, and especially in Iran, widespread groundwater distribution and consumption networks have been implemented to support agricultural activities [VAN DER GUN et al. 2007]. Accounting for roughly $94 \%$ of the nation's annual water usage, Iran's agricultural sector is the nation's biggest water resource stakeholder [AlizADEH, KeshavarZ 2005]. Given the potential effects of irrigation water on cultivated soils and crops, the assessment and monitoring of water quality are important to decision-makers. Accordingly, the Food and Agriculture Organization of the United Nations (FAO) has published water quality guidelines for the agriculture sector.

Compared to surface water, groundwater carries a greater quantity and variety of dissolved minerals, complicating the assessment of its quality. Variations in crop tolerance for different minerals adds to this challenge [ABBASI, ABBASI 2012]. Variation in groundwater quality is tied to a range of factors, including regional hydrogeology, geochemical processes, irrigation return flows, cation exchange and anthropogenic activities [GORGIJ, VADIATI 2014; VADIATI et al. 2013]. Groundwater is subject to the poorly understood process of hydrochemical evolution as it passes through different soil layers and geologic formations, and moves from recharge to discharge areas [SINGH et al. 2013].

Many diagrammatic and graphical techniques can be used to represent the hydrochemical characteristics of water destined for agricultural applications [DONEEN 1962; PIPER 1944; SCHOELLER 1962; STIFF 1951; USSL 1954; WILCOX 1955]. Given the lack of precision in these diagrams, particularly for marginal samples, their interpretation can prove challenging. The widely-used United States Salinity Laboratory (USSL) water quality classification system for agricultural production applications, which draws solely on electrical conductivity $(E C)$ and sodium adsorption ratio $(S A R)$, and ignores other critical indices (e.g., magnesium adsorption ratio $(M A R)$, soluble sodium percentage $(S S P)$, Kelly's ratio $(K R)$, residual sodium carbonate $(R S C)$ and permeability index $(P I))$, is ill-suited for water quality assessment. Among these techniques are water quality assessments and modelling methods involving multi-criteria decision-making that must also consider qualitative and quantitative uncertainties and their transformation [WANG et al. 2016]. The fact that many samples may be classified within a single category obscures the interpretation of USSL results, complicating decisionmaking and highlighting the need for models that address these issues. Moreover, deterministic approaches and graphical techniques cannot account for uncertainty throughout the water quality assessment process. In the current study, the researchers propose to overcome these limitations in water quality assessment by: (i) using fuzzy logic (FL) and (ii) developing generalized models to evaluate groundwater quality using important irrigation indices.

Among the many discussions of water quality criteria selection for decision-making in the literature, a great number have noted the inability of deterministic approaches to monitor uncertainty throughout the entire decision- making process [DAHIYA et al. 2007]. Ambiguity and the absence of inherent certainty, differing standards and decision-making units, along with challenges regarding judgment, have led water resources researchers to explore fuzzy set theory and FL [BARDOSSY et al. 1995]. Based on the consideration of water quality assessment as a fuzzy concept involving many indicators and classes, comprehensive fuzzy evaluation methods have recently been developed and evaluated for their potential use in water quality assessment [DANGE, LAD 2017; WANG et al. 2014].

While studies have applied surface water quality criteria to groundwater quality evaluation for agricultural purposes, few studies have directly addressed groundwater quality. Similarly, while many studies have discussed the applications of FL in water resources evaluation, these have been largely limited to the assessment of water quality for potable uses [DAHIYA et al. 2007; HOSSEINI-MOGHARI et al. 2015; VADIATI et al. 2016]. Accordingly, further research on water quality assessment, particularly in the context of groundwater use for agricultural purposes, is necessary [AlAVI et al. 2010; MIRABBASI et al. 2008; OSTOVARI et al. 2015].

The current study's novelty arises from its development of generalized rule-based fuzzy models for water quality evaluation using widely accepted irrigation indices. This research attempts to fill gaps in water quality evaluation model theory by applying three types of FL models: Sugeno (SFL), Mamdani (MFL) and Larsen (LFL). While these three models normally achieve similar levels of accuracy, each has different strengths and weaknesses. In this study, they were used to develop new fuzzy inference system (FIS) models for agricultural applications. To deal with the inherent uncertainty in groundwater quality assessment, a comprehensive FL rule-based decision model was built based on expert knowledge.

\section{STUDY METHODS}

\section{USSL-DIAGRAM FOR IRRIGATION WATER QUALITY EVALUATION}

The USSL diagram [USSL 1954] (see: Fig. 1) targets agricultural production, and draws on two important physiochemical criteria ( $S A R$ and $E C$ ), and is a widely accepted system for water quality classification. The USSL diagram is divided into different salinity zones based on $E C$ : low $\left(<0.025 \mathrm{~S} \cdot \mathrm{m}^{-1}\right)$, medium $\left(0.025-0.075 \mathrm{~S} \cdot \mathrm{m}^{-1}\right)$, high $(0.075$ $\left.0.225 \mathrm{~S} \cdot \mathrm{m}^{-1}\right)$ and very high $\left(0.225-0.500 \mathrm{~S} \cdot \mathrm{m}^{-1}\right)$ [USSL 1954].

\section{IRRIGATION INDICES}

The suitability of groundwater for irrigation is influenced by factors such as soil type, soil drainage, salt tolerance and crop type [MicHAEL 2008]. Among the most frequently used water quality evaluation criteria are the SAR, MAR, EC, SSP, KR, RSC and PI. SAR represents the alkalinity hazard to crops [RAGHUNATH 1987]; excessive sodium in water can stunt plant growth and deteriorate soil structure through the dispersion of clay particles, harden 




Fig. 1. USSL diagram classes for evaluation of irrigation waters; source: USSL [1954]

soil, and cause surface crusting and the alteration of soil hydraulic conductivity [RAMESH, ELANGO 2012; SUAREZ et al. 2006]. Since high levels of sodium can reduce soil permeability, the $S S P$ is important in groundwater quality evaluation for irrigation purposes. Irrigation water $R S C$ assesses water acceptability for irrigation purposes [HOWARI et al. 2005] and correlates with the adsorption of sodium to the soil [EATON 1950]. Accordingly, for irrigation purposes, water is not suitable when $R S C>2.5 \mathrm{mmol}$ $\mathrm{Na} \cdot \mathrm{dm}^{-3}$, and is deemed harmful when $R S C>5 \mathrm{mmol}$ $\mathrm{Na} \cdot \mathrm{dm}^{-3}$. DONEEN [1962] assessed irrigation water quality using the $P I$ as long-term irrigation can affect soil permeability. A high magnesium ratio in irrigation groundwater decreases soil quality and crop yield [GowD 2005]. PALIWAL [1972] introduced the $M A R$ index as a measure of magnesium hazard, where $M A R>50$ and $M A R<50$ indicate whether groundwater is unsafe or safe for irrigation purposes, respectively. The $K R$ is based on the ratio of measured sodium to calcium and magnesium [KELLEY 1940], where $K R<1.0$ and $K R>1.0$ indicate suitable and unsuitable water for irrigation, respectively. $E C$ reflects the dissolved constituents present in groundwater, and when elevated, reduces the absorption of nutrients and water from the soil and increases soil solution osmotic pressure [MARGHADE et al. 2011].

\section{FUZZY INFERENCE SYSTEM (FIS)}

The concept of FL, proposed by ZADEH [1965], has been applied in many science and technology fields. FISs normally consist of three main steps: 1) fuzzification, 2) fuzzy rule base, and 3) defuzzification. One of the main advantages of FIS is that it tolerates various types of uncertainty.
The fuzzy sets assign a domain for the interval $[0,1]$ :

$$
A=\left\{\left(x_{1}, \mu_{A}(x)\right) \mid x \in X\right\}, \quad o \leq \mu_{A}(x)=1
$$

Where: $\mu_{A}(x)$ is the membership function (MF) of $x$ in $A$.

A fuzzy set's level of fuzziness is determined through the selection of the MF membership values (ranging from 0 to 1 ) and shape (e.g., trapezoidal, triangular, etc.) [KUSKO 1993]. Qualitative aspects of expert knowledge are transferred as "if-then" rules [ZADEH 1965]. Since fuzzy inference rule-based systems accommodate different types of uncertainty and vagueness that influence results, FISs are helpful in water management decision-making [LERMONTOV et al. 2009]. A FIS is comprised of elements such as MFs, logical operations and fuzzy rules [ZADEH 1965]. The aggregation of separate rules is accomplished by means of a conjunctive and/or disjunctive system, such that logical outputs are subsequently extracted for all rules. In conjunctive and disjunctive systems, rules are connected by "and" and "or" connectives, respectively [Ross 2012].

\section{FUZZIFICATION}

Different types of MFs, both linear and nonlinear, are involved in the construction of the fuzzification process. The MF of a trapezoidal fuzzy set is calculated as [Ross 2012]:

$f(x ; a, b, c, d)=\left\{\begin{array}{cc}0 x<\frac{a}{d}<x \frac{(a-x)}{(a-b)} & a \leq x \leq b \\ b \leq x \leq c \frac{(d-x)}{(d-c)} & c \leq x \leq d\end{array}\right\}$

Where $a, b, c$ and $d$ are constants.

\section{FUZZY RULE BASE}

The rule base, known as fuzzy "if-then" rules, is included in linguistic terms prepared by experts or based on extractions from the data set. Every rule consists of a mathematical methodology that transfers expert knowledge into fuzzy "if-then" rules. The fuzzy rules are comprised of two parts; the antecedent (the "if" part) and the consequent (the "then" part) [WANG et al. 2009].

\section{DEFUZZIFICATION}

The procedure of converting a fuzzy output into a crisp value is called defuzzification. Frequently used defuzzification operators include the centroid of area (COA), calculated as:

$$
Y_{C O A}^{*}=\frac{\int_{Y} \mu_{A}(Y) Y d Y}{\int_{Y} \mu_{A}(Y) d Y}
$$

Where: $Y_{C O A}^{*}$ is the fuzzy output converted into a crisp value and $\mu_{A}(Y)$ is the aggregation of the output MF [WANG et al. 2009].

\section{FUZZY LOGIC-BASED MODELS}

The main advantage of FL-based models is their capacity to handle both numerical and linguistic terms simul- 
taneously [VADIATI et al. 2016]. Additionally, the models are transparent with regards to the fuzzy system as they use "if-then" rules and MFs. As such, FL models are straightforward and can be used in many practical applications for modelling and control of complex systems. The many FIS models found in the literature can generate outputs that differ significantly. The most well-known FIS model types (e.g., Mamdani [MAMDANI, ASSILIAN 1975], Sugeno [TAKAGI, SUGENO 1985] and Larsen [LARSEN 1980]; MFL, SFL and LFL, respectively) follow an "if antecedence then consequence" pattern. While all fuzzy models share the same antecedence, consequence comes in different forms for different models. Further inter-model differences are based on their formulation of fuzzy "if-then" rules, aggregated rules and the defuzzification process. In zero or firstorder SFL models, the output MFs are constant or linear, whereas the MFL and LFL model outputs are fuzzy sets, which then require defuzzification.

A typical rule base in MFL has the form, $R^{i}=$ if $x$ is $A_{i}$ and $y$ is $B_{i}$ then $z$ is $C_{i}$ $i=1,2, \ldots, n$ then $R^{i}=\left(A_{i} \cap B_{i}\right) \rightarrow C_{i}$ is defined by $\mu_{R_{i}}=\mu_{\left(A_{i} \text { and } B_{i} \rightarrow C_{i}\right)}(x, y, z)$. A typical rule base in LMF, $R^{i}=$ if $x$ is $A_{i}$ and $y$ is $B_{i}$ then $z$ is $C_{i} i=1,2, \ldots, n$ then $R^{i}=\left(A_{i} \cap B_{i}\right) \rightarrow C_{i}$ is defined by $\mu_{R_{i}}=$ $\mu_{\left(A_{i} \cap B_{i} \rightarrow C_{i}\right)}(x, y, z)$. In SFL, the rule structure is based on if Input $1=x_{0}$ and Input $2=y_{0}$, then $z=p x_{0}+q y_{0}+r$. For a zero-order Sugeno model, the output level is a constant $(p=q=0)$ [TAKAGI, SugENO 1985]. A graphical illustration of the MFL, LFL and SFL models are shown in Figure 2.

\section{STUDY AREA AND DATA}

The Sarab Plain is located in northwestern Iran. The Sabalan Mountain, situated in the northern part of the study area, has the highest and lowest elevations of $4850 \mathrm{~m}$ and $1660 \mathrm{~m}$ a.s.1., respectively. The study area has an average annual rainfall of $343 \mathrm{~mm}$ and an average annual temperature of $7.9^{\circ} \mathrm{C}$. The Sarab alluvial aquifer originates from the weathering of the Sabalan and Bozqoush mountain ranges. The main outcrops in the Sarab plain consist of: andesite, dacite, basalt, evaporate sediments, conglomerate, siltstone, and marl, which may have an impact on groundwater quality. The groundwater level fluctuation in the unconfined Sarab aquifer is due mostly to precipitation, river recharge, irrigation return flows to groundwater and intensive groundwater withdrawal [VADIATI et al. 2016]. The hydrochemical composition of groundwater in the Sarab Plain is strongly controlled by geology, hydrogeology and evaporation minerals within Miocene sediment formations. The verification of FL methods is improved through the use of general data. Therefore, hydrogeological uncertainty and the intensive impact of agricultural activities in the Sarab Plain made this study area ideal for checking the applicability of FL models with respect to regional and seasonal variability in groundwater quality.

Increasing demand for water supplies at new farms has led to excessive deep well drilling and the subsequent over-extraction of groundwater in the plain. As a result, deterioration of groundwater quality has recently become a major concern. To assess groundwater quality, a total of 49 well samples were collected in the wet season, specifically in April 2015, and their hydrochemical parameters analysed based on standard procedures outlined by the American Public Health Association [APHA, AWEF 1998]. The physical parameters (EC, $\mathrm{pH}$ and temperature) were measured in situ and hydrochemical, physiochemical and ion balance error analysis was carried out in a laboratory at the University of Tabriz, Iran. The sampling sites and the water resources map of the Sarab Plain is presented in Figure 3.

\section{MODEL DEVELOPMENT}

The main aim of the present study was to explore FL rule-based decision models based on important irrigation indices with the aim of replacing conventional classification diagrams that have parameter selection insufficiencies. 




Fig. 3. The sampling sites and water resources map of the Sarab Plain, Iran; source: own elaboration

The general process used to develop a fuzzy rule-based model for agricultural purposes is presented in Figure 4. The procedure begins with the selection of sampling loca- tions and groundwater quality indices. This is followed by fuzzification of groundwater quality parameters, fuzzy rule design based on expert knowledge and datasets, and finally, the development of the MFL, SFL and LFL models.

Since water quality degradation can be caused by various environmental factors acting simultaneously, indices most appropriate to local environments and most relevant to the quality of groundwater should be selected. Selecting a suitable number of relevant indices is also necessary to define the main concerns of management and to facilitate efficient restoration and conservation efforts for water resources.

Fuzzy-logic models based on measured data have been receiving more attention than traditional fuzzy models, which in general, strictly employ linguistic rules. The MFL, SFL and LFL models developed in this research can provide groundwater quality assessment for agricultural purposes. In the current study, a number of irrigation water indices relevant to water quality (e.g., $E C, S A R, S S P, R S C$, $P I, M A R$ and $K R$ ) were selected as input parameters in the development of the FIS models. More specifically, these indices were used to develop the generalized fuzzy models based on the prescribed ranges of each parameter. The

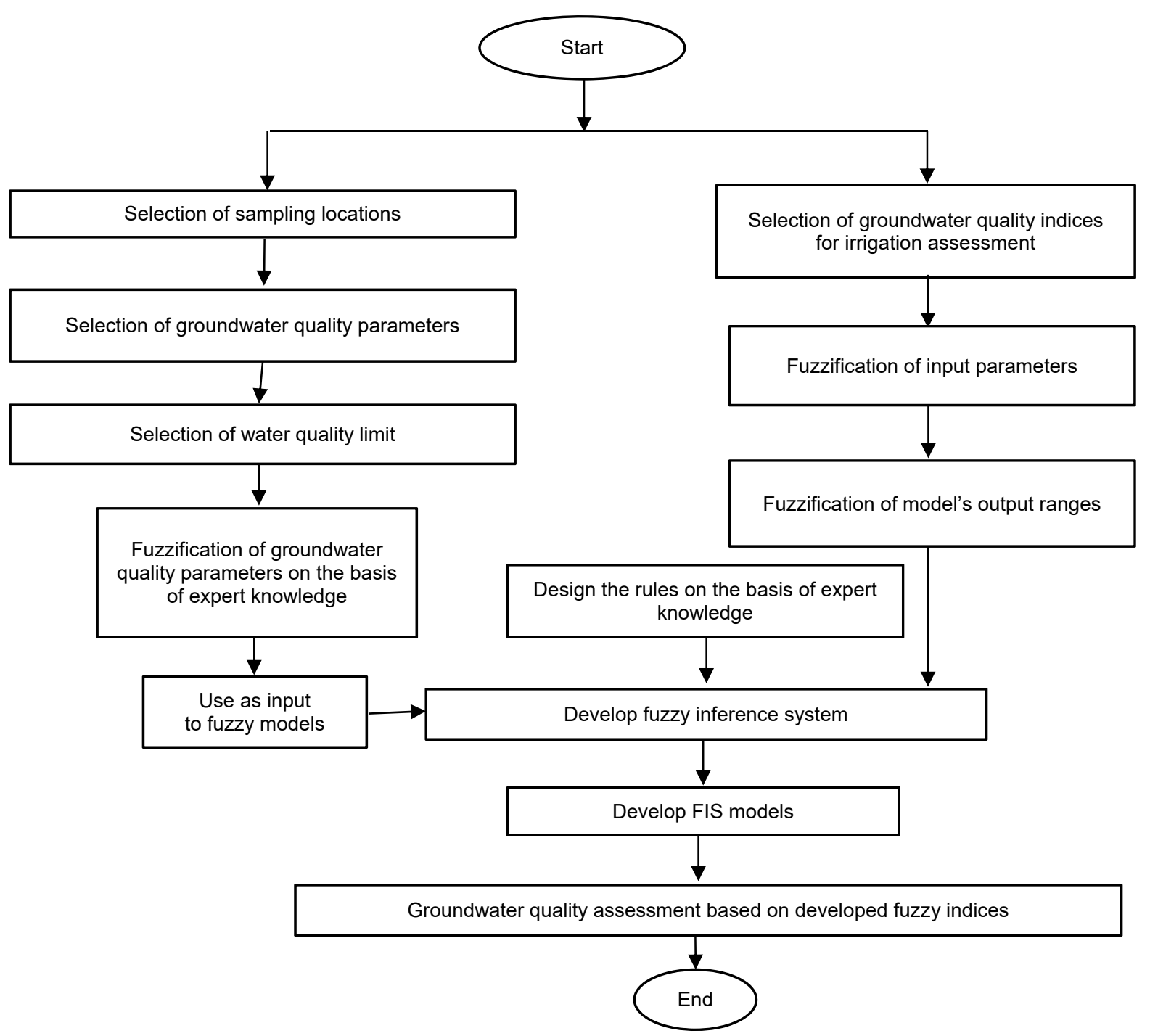

Fig. 4. The general process to develop the fuzzy inference system (FIS) models; source: own elaboration 
structure of the proposed fuzzy models is depicted in Figure 5. The process was executed using MATLAB [MathWorks 2014]. The FISs transfer of expert judgment was expressed as "if-then" rules. In the antecedent "if" component, the model input parameters $S A R, S S P, R S C, P I, M A R$, $K R$, and $E C$, were each categorized into three linguistic terms: "low", "moderate", and "high". In the consequent "then" element, the model outputs were categorized as "desirable", "acceptable", and "unacceptable".

Appropriate methods for evaluating FL models depend strongly on the number of fuzzy sets. Several MF shapes can exist, however, simple "trapezoid" MFs work well [BARUA et al. 2013]. In the present study, triangular and trapezoidal MFs were used according to the nature of the hydrochemical parameters and information available from past studies and research. Moreover, to achieve an ideal
FIS, the type of MFs were selected according to a trial and error process involving expert input. For example, Figure 6 shows the MF of the SSP input parameter.

Fuzzy sets determine each input MF, thereby defining fuzzy sets in terms of degrees of membership, ranging from 0 to 1 . Table 1 shows the parameter MFs used in the inference fuzzy model in this study. The rules for the model were constructed based on information drawn from the effects of physicochemical input parameters on soil and crop quality. The number of rules in the fuzzy inference model depends on input parameters and linguistic terms. Generally, the weight of every rule is a number between 0 and 1; rule weights were set at 1 in the present study.

After the fuzzy rules are determined, the structure of the FL model must be designed. Using an implication process, the previously-developed rules served to transform

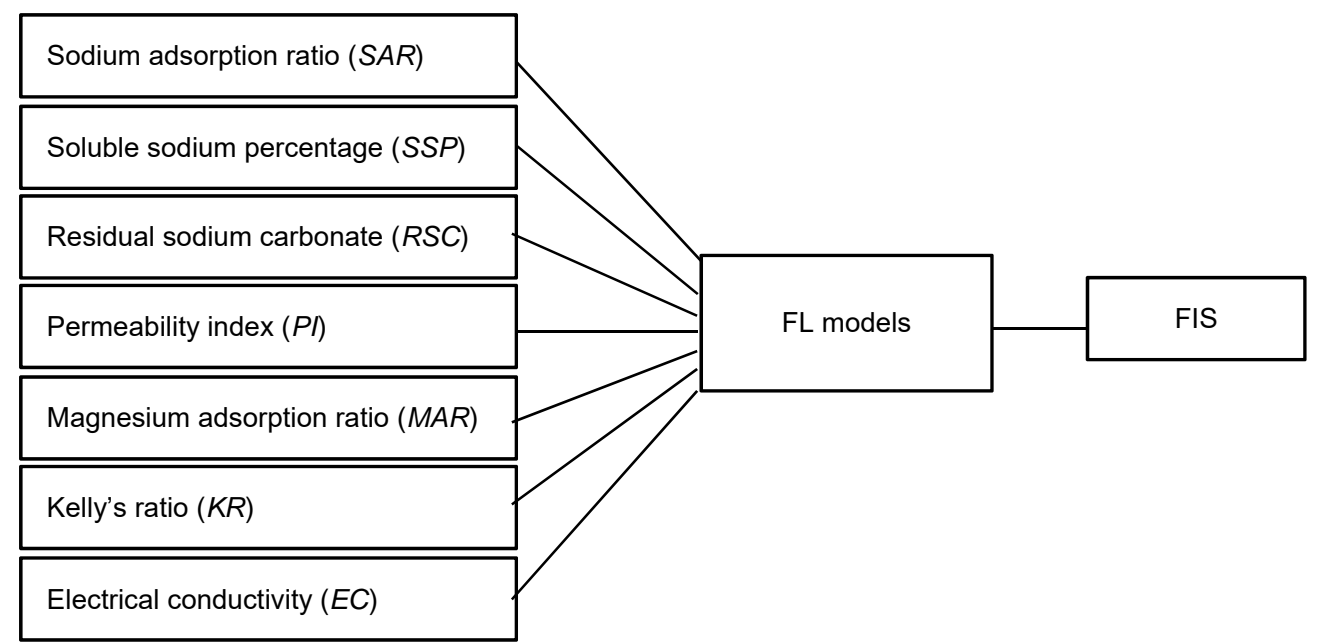

Fig. 5. A schematic illustration of the fuzzy inference (FIS) models used in the current study; electrical conductivity (EC), sodium adsorption ratio $(S A R)$, magnesium adsorption ratio $(M A R)$, soluble sodium percentage $(S S P)$, Kelly's ratio $(K R)$, residual sodium carbonate $(R S C)$, permeability index $(P I)$, fuzzy logic $(\mathrm{FL})$, fuzzy inference system (FIS); source: own elaboration



Fig. 6. Membership function of the soluble sodium percentage (SSP); source: own elaboration

Table 1. The parameter membership functions used in inference fuzzy models

\begin{tabular}{|c|c|c|c|c|c|c|c|c|c|c|}
\hline \multirow[t]{2}{*}{ Input model } & \multicolumn{3}{|c|}{ High } & \multicolumn{4}{|c|}{ Moderate } & \multicolumn{3}{|c|}{ Low } \\
\hline & $\mathrm{c}=\mathrm{d}$ & $\mathrm{b}$ & $\mathrm{a}$ & $\mathrm{d}$ & $\mathrm{c}$ & $\mathrm{b}$ & $\mathrm{a}$ & $\mathrm{d}$ & $\mathrm{c}$ & $a=b$ \\
\hline Sodium adsorption ratio & 50 & 14 & 10 & 13 & 10 & 7 & 3 & 7 & 4 & 0 \\
\hline Soluble sodium percentage & 100 & 67 & 55 & 67 & 57 & 42 & 28 & 42 & 35 & 0 \\
\hline Residual sodium carbonate & 9 & 2.8 & 2 & 3.5 & 2.5 & 1.25 & 0.5 & 1.5 & 0.5 & -13.1 \\
\hline Permeability index & 100 & 62 & 50 & 62 & 56 & 42 & 33 & 44 & 36 & 0 \\
\hline Magnesium adsorption ratio & 100 & 63 & 55 & 66 & 58 & 44 & 36 & 42 & 35 & 0 \\
\hline Kelley's ratio & 9 & 0.9 & 0.65 & 0.9 & 0.65 & 0.5 & 0.3 & 0.5 & 0.35 & 0 \\
\hline Electrical conductivity & 4000 & 3400 & 2800 & 3500 & 3000 & 780 & 600 & 800 & 695 & 0 \\
\hline
\end{tabular}

Explanations: $\mathrm{a}, \mathrm{b}, \mathrm{c}$, and $\mathrm{d}=$ membership function parameters.

Source: own study. 
the input MFs into a single MF defined as the output variable. The outputs of every rule were separately aggregated into a single fuzzy set, which was then used as the input for the defuzzification procedure. For the implication procedure, the "min" and "product" operators were used in MFL and LFL models, respectively. For both the MFL and LFL techniques, the COA defuzzification method, a wellknown and widely used technique, was used to obtain the crisp output values [HELLENDOORN, THOMAS 1993].

\section{RESULTS}

\section{EVALUATION OF GROUNDWATER QUALITY USING THE USSL DIAGRAM}

The USSL classification diagram (Fig. 7) of groundwater classifies water samples into several categories, e.g., C1-S1, C2-S1, C3-S1, C3-S2, C4-S2 and C4-S4. Twenty-four samples were classified as $\mathrm{C} 2-\mathrm{S} 1$, meaning that they posed no hazard of sodium exchange in soils for agricultural use. Twenty samples were in the C3-S1 class, meaning that there was little hazard of sodium exchange. One sample was in the $\mathrm{C} 1-\mathrm{S} 1$ class, indicating that the water had a low saline level and was acceptable in each type of soil for agricultural use. One sample was placed in each of the $\mathrm{C} 3-\mathrm{S} 2$ and $\mathrm{C} 4-\mathrm{S} 2$ classes, which represent high and very high salinity water, respectively; both classes indicated the need for specific soil management practices in the case of agricultural use. The remaining two samples were classified as $\mathrm{C} 4-\mathrm{S} 4$, indicating that the water was highly saline and unacceptable for agricultural use.

The spatial distribution of groundwater samples in the Sarab Plain, as classified by the USSL classification dia-

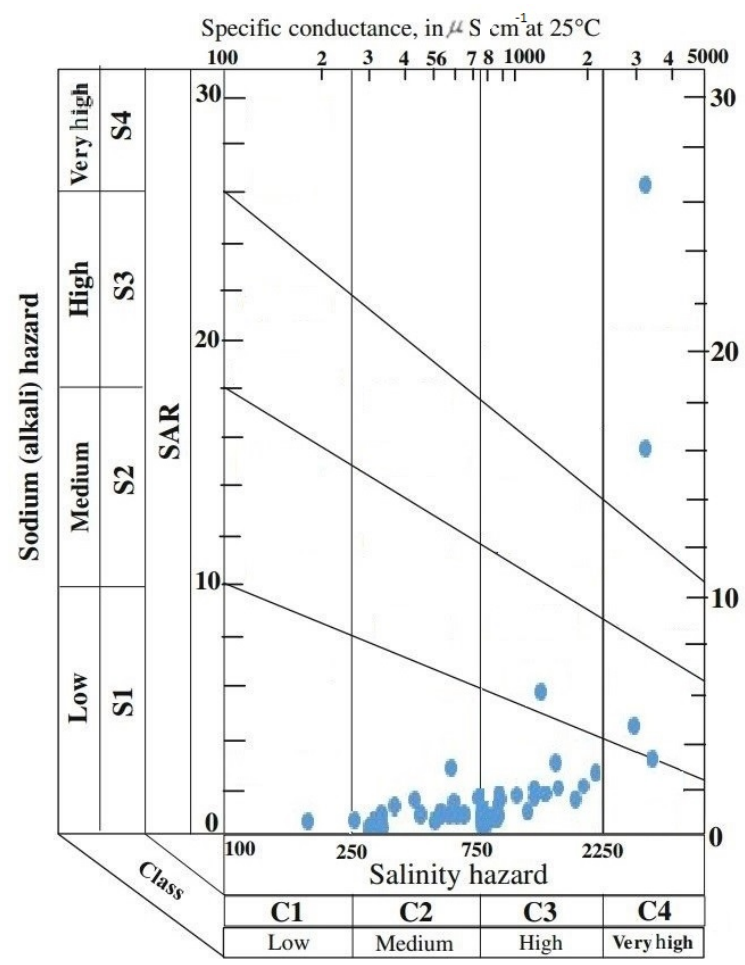

Fig. 7. The USSL diagram classification of groundwater samples from the Sarab Plain; source: own study gram, showed that samples in the $\mathrm{C} 2-\mathrm{S} 1$ class were found largely in the east where the aquifer is recharged from streams (Fig. 8). Samples in the moderate water quality C3-S1 class were found mainly in the middle section of the study area, where groundwater quality deteriorates due to the dissolution of gypsum and mineral salts from Miocene formations, cation exchange and urban wastewater. The sample in the C4-S2 class was located in the northern region of the Sarab Plain, where salinity and $S A R$ increased as a result of aquifer recharge from the saline waters of the Talkheh Rud River [ASADOLLAHFARDI et al. 2011].

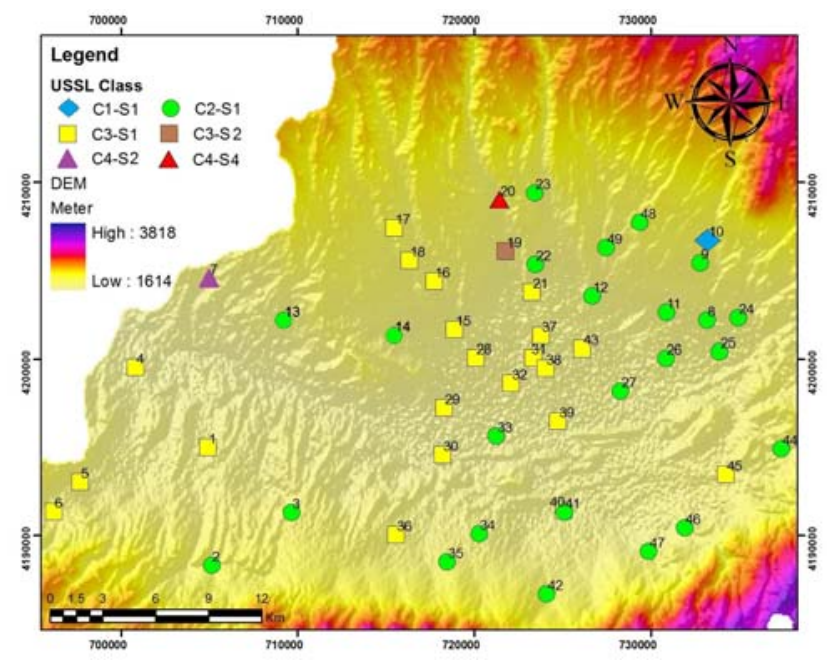

Fig. 8. Spatial USSL classification diagram of groundwater samples in the Sarab Plain, Iran; source: own study

\section{IRRIGATION INDICES}

The key indices, SAR, PI, KR, MAR, RSC, SSP and EC were used to determine the water quality for agricultural purposes. In the study area samples, $K R$ ranged between 0.03 and 7.6, and $P I$ ranged between 29.4 and 92.1. A summary of the irrigation indices of groundwater samples from the Sarab Plain is shown in Table 2. A plot of the spatial variation of irrigation indices in the Sarab Plain (Fig. 9) shows a complex pattern, precluding simple conclusions regarding the varying behaviour of each index. For example, higher values of $E C, S S P$ and MAR were apparent in the northern/northwestern, central, and northeast/south-west parts of the Sarab Plain, respectively. In contrast, the distribution of $P I$ was found to be highly variable.

Table 2. Summary of irrigation indices in groundwater of the Sarab Plain

\begin{tabular}{|l|c|c|c|c|c|c|c|}
\hline \multicolumn{1}{|c|}{ Statistic } & $S S P$ & $R S C$ & $P I$ & $M A R$ & $K R$ & $E C$ & $S A R$ \\
\hline Minimum & 7.5 & -13.1 & 29.4 & 9.5 & 0.03 & 185 & 0.08 \\
\hline Maximum & 75.9 & 8.2 & 91.2 & 51.1 & 7.6 & 3400 & 27.2 \\
\hline Mean & 53.0 & -0.9 & 55.3 & 28.7 & 0.6 & 952 & 2.6 \\
\hline Standard deviation & 12.9 & 3.6 & 14.4 & 10.1 & 1.2 & 750 & 6.9 \\
\hline
\end{tabular}

Explanations: $S S P=$ soluble sodium percentage, $R S C=$ residual sodium carbonate, $P I=$ permeability index, $M A R=$ magnesium adsorption ratio, $K R=$ Kelly's ratio, $E C=$ electrical conductivity $\left(\mu \mathrm{S} \cdot \mathrm{cm}^{-1}\right), S A R=$ sodium adsorption ratio. All ion concentration of the parameters were expressed in $\mathrm{mg} \cdot \mathrm{dm}^{-3}$.

Source: own study. 



Fig. 9. Spatial variation of irrigation indices in groundwater of the Sarab Plain, Iran; $K R=$ Kelly's ratio, $E C=$ electrical conductivity, $S A R=$ sodium adsorption ratio, $M A R=$ magnesium adsorption ratio, $S S P=$ soluble sodium percentage, $R S C=$ residual sodium carbonate, $P I=$ permeability index; source: own study 


\section{RESULTS OF THE FUZZY INFERENCE SYSTEM MODELS}

The comparison of groundwater quality classes using the proposed FL methods and the USSL diagram (Tab. 3) shows that, for sample number 1 , for example, input parameters of $S A R=2, S S P=47.5, K R=0.5, M A R=31.6$,
$R S C=-2.1, P I=51.3$ and $E C=1510 \mu \mathrm{S} \cdot \mathrm{cm}^{-1}$, led to the sample being classified as "acceptable" by the FL approaches (MFL, LFL and SFL), and to fall within the C3S1 category of the USSL classification. Many samples were situated on the border between the USSL C2-S1 and C3-S1 categories (Fig. 7). Therefore, the inherent uncertainty in various steps of groundwater quality assessment,

Table 3. Comparison of groundwater quality classes using fuzzy logic and USSL class

\begin{tabular}{|c|c|c|c|c|c|c|c|c|c|c|c|}
\hline \multirow[b]{2}{*}{ No. } & \multicolumn{7}{|c|}{ Crisp values of input parameters } & \multicolumn{3}{|c|}{ Decision-making based on fuzzy logic-based models } & \multirow[b]{2}{*}{$\begin{array}{l}\text { USSL } \\
\text { class }\end{array}$} \\
\hline & $S A R$ & SSP & $K R$ & $M A R$ & $R S C$ & $P I$ & $E C$ & $\begin{array}{l}\text { Mamdani model } \\
\text { (MFL) }\end{array}$ & $\begin{array}{l}\text { Larsen model } \\
\text { (LFL) }\end{array}$ & $\begin{array}{l}\text { Sugeno model } \\
\text { (SFL) }\end{array}$ & \\
\hline 1 & 2.0 & 47.5 & 0.5 & 31.6 & -2.1 & 51.3 & 1510 & acceptable & acceptable & acceptable & C3-S1 \\
\hline 2 & 0.8 & 59.0 & 0.2 & 27.8 & -1.2 & 48.5 & 580 & desirable & desirable & desirable & $\mathrm{C} 2-\mathrm{S} 1$ \\
\hline 3 & 0.5 & 64.6 & 0.2 & 25.0 & -0.9 & 48.4 & 510 & desirable & desirable & desirable & $\mathrm{C} 2-\mathrm{S} 1$ \\
\hline 4 & 3.2 & 29.0 & 0.7 & 51.1 & -3.9 & 55.5 & 1460 & acceptable & acceptable & acceptable & $\mathrm{C} 3-\mathrm{S} 1$ \\
\hline 5 & 1.7 & 38.0 & 0.4 & 46.1 & -2.3 & 51.8 & 1020 & acceptable & acceptable & acceptable & C3-S1 \\
\hline 6 & 1.5 & 37.5 & 0.4 & 50.0 & -2.2 & 47.1 & 880 & acceptable & acceptable & acceptable & C3-S1 \\
\hline 7 & 3.5 & 51.4 & 0.5 & 25.6 & -19.7 & 38.9 & 3400 & unacceptable & unacceptable & unacceptable & C4-S2 \\
\hline 8 & 0.1 & 62.1 & 0.0 & 36.8 & -0.6 & 53.3 & 290 & desirable & desirable & desirable & $\mathrm{C} 2-\mathrm{S} 1$ \\
\hline 9 & 0.2 & 57.4 & 0.1 & 40.5 & -0.8 & 51.3 & 325 & desirable & desirable & desirable & $\mathrm{C} 2-\mathrm{S} 1$ \\
\hline 10 & 0.3 & 46.6 & 0.1 & 48.1 & -0.6 & 62.1 & 185 & desirable & desirable & desirable & $\mathrm{C} 1-\mathrm{S} 1$ \\
\hline 11 & 0.3 & 59.2 & 0.1 & 33.3 & -0.3 & 62.5 & 290 & desirable & desirable & desirable & $\mathrm{C} 2-\mathrm{S} 1$ \\
\hline 12 & 1.5 & 51.7 & 0.4 & 26.4 & -2.1 & 53.8 & 740 & acceptable & acceptable & desirable & $\mathrm{C} 2-\mathrm{S} 1$ \\
\hline 13 & 5.2 & 38.3 & 0.9 & 27.6 & -12.7 & 53.8 & 3000 & desirable & desirable & desirable & $\mathrm{C} 2-\mathrm{S} 1$ \\
\hline 14 & 2.8 & 54.0 & 0.5 & 19.5 & -7.4 & 45.9 & 2130 & desirable & desirable & desirable & $\mathrm{C} 2-\mathrm{S} 1$ \\
\hline 15 & 2.0 & 53.0 & 0.5 & 23.0 & -6.0 & 44.6 & 1200 & acceptable & acceptable & acceptable & C3-S1 \\
\hline 16 & 1.5 & 66.2 & 0.3 & 16.3 & -12.6 & 29.4 & 1765 & acceptable & acceptable & acceptable & $\mathrm{C} 3-\mathrm{S} 1$ \\
\hline 17 & 0.6 & 69.3 & 0.2 & 20.5 & -5.0 & 31.0 & 847 & acceptable & acceptable & acceptable & C3-S1 \\
\hline 18 & 1.8 & 54.9 & 0.4 & 24.1 & -6.1 & 42.7 & 1330 & acceptable & acceptable & acceptable & C3-S1 \\
\hline 19 & 6.1 & 30.7 & 1.9 & 17.7 & 2.9 & 85.2 & 1300 & unacceptable & unacceptable & unacceptable & C3-S2 \\
\hline 20 & 15.6 & 20.0 & 4.2 & 16.3 & 7.1 & 91.2 & 3230 & unacceptable & unacceptable & unacceptable & C4-S4 \\
\hline 21 & 0.9 & 63.2 & 0.2 & 23.0 & -1.4 & 47.5 & 760 & desirable & acceptable & acceptable & C3-S1 \\
\hline 22 & 0.8 & 64.3 & 0.3 & 20.1 & -0.8 & 53.3 & 660 & desirable & desirable & desirable & $\mathrm{C} 2-\mathrm{S} 1$ \\
\hline 23 & 2.8 & 42.2 & 1.3 & 13.1 & 0.9 & 89.2 & 584 & acceptable & acceptable & desirable & $\mathrm{C} 2-\mathrm{S} 1$ \\
\hline 24 & 1.3 & 50.4 & 0.4 & 28.8 & -0.6 & 60.9 & 600 & desirable & desirable & desirable & $\mathrm{C} 2-\mathrm{S} 1$ \\
\hline 25 & 0.8 & 48.8 & 0.2 & 40.7 & -2.1 & 46.6 & 620 & desirable & desirable & desirable & $\mathrm{C} 2-\mathrm{S} 1$ \\
\hline 26 & 0.2 & 49.9 & 0.1 & 46.7 & -1.0 & 46.8 & 310 & desirable & desirable & desirable & $\mathrm{C} 2-\mathrm{S} 1$ \\
\hline 27 & 0.5 & 52.8 & 0.2 & 36.4 & 0.0 & 70.2 & 254 & desirable & desirable & desirable & $\mathrm{C} 2-\mathrm{S} 1$ \\
\hline 28 & 1.0 & 56.7 & 0.2 & 31.0 & -4.7 & 37.0 & 1130 & acceptable & acceptable & acceptable & C3-S1 \\
\hline 29 & 2.1 & 56.6 & 0.4 & 23.1 & -12.5 & 36.1 & 1900 & acceptable & acceptable & acceptable & C3-S1 \\
\hline 30 & 47.2 & 7.5 & 7.7 & 36.0 & -14.2 & 89.8 & 3400 & unacceptable & unacceptable & unacceptable & C4-S4 \\
\hline 31 & 1.8 & 55.1 & 0.5 & 18.0 & -2.6 & 54.7 & 870 & acceptable & acceptable & acceptable & C3-S1 \\
\hline 32 & 1.8 & 52.5 & 0.4 & 28.7 & -5.2 & 43.2 & 1350 & acceptable & acceptable & acceptable & C3-S1 \\
\hline 33 & 0.8 & 69.6 & 0.3 & 9.5 & -0.6 & 59.7 & 450 & desirable & desirable & desirable & $\mathrm{C} 2-\mathrm{S} 1$ \\
\hline 34 & 0.4 & 61.6 & 0.2 & 28.4 & -0.1 & 64.5 & 310 & desirable & desirable & desirable & $\mathrm{C} 2-\mathrm{S} 1$ \\
\hline 35 & 1.1 & 48.1 & 0.5 & 29.9 & 0.0 & 71.4 & 360 & desirable & desirable & desirable & $\mathrm{C} 2-\mathrm{S} 1$ \\
\hline 36 & 0.9 & 58.0 & 0.2 & 30.3 & -3.6 & 38.6 & 835 & acceptable & acceptable & acceptable & C3-S1 \\
\hline 37 & 0.6 & 63.0 & 0.1 & 28.1 & -2.5 & 39.4 & 800 & acceptable & acceptable & acceptable & C3-S1 \\
\hline 38 & 0.8 & 63.4 & 0.2 & 24.0 & -2.5 & 41.1 & 870 & acceptable & acceptable & acceptable & C3-S1 \\
\hline 39 & 1.6 & 53.7 & 0.4 & 27.0 & -6.1 & 41.3 & 1200 & acceptable & acceptable & acceptable & C3-S1 \\
\hline 40 & 0.3 & 62.5 & 0.1 & 33.0 & -1.7 & 36.6 & 760 & acceptable & desirable & acceptable & C3-S1 \\
\hline 41 & 0.5 & 55.3 & 0.2 & 34.8 & -0.7 & 55.0 & 320 & desirable & desirable & desirable & C2-S1 \\
\hline 42 & 0.4 & 53.7 & 0.1 & 38.5 & -0.6 & 56.0 & 300 & desirable & desirable & desirable & $\mathrm{C} 2-\mathrm{S} 1$ \\
\hline 43 & 0.7 & 75.9 & 0.2 & 11.2 & -2.6 & 39.5 & 800 & acceptable & acceptable & acceptable & C3-S1 \\
\hline 44 & 0.9 & 54.5 & 0.3 & 31.8 & -0.2 & 57.7 & 540 & desirable & desirable & desirable & $\mathrm{C} 2-\mathrm{S} 1$ \\
\hline 45 & 1.3 & 56.1 & 0.3 & 26.0 & -2.8 & 46.1 & 860 & acceptable & acceptable & acceptable & C3-S1 \\
\hline 46 & 0.5 & 68.1 & 0.2 & 17.1 & -0.1 & 64.4 & 300 & desirable & desirable & desirable & $\mathrm{C} 2-\mathrm{S} 1$ \\
\hline 47 & 0.8 & 68.8 & 0.2 & 14.5 & 0.1 & 56.0 & 540 & desirable & desirable & desirable & $\mathrm{C} 2-\mathrm{S} 1$ \\
\hline 48 & 0.8 & 50.7 & 0.3 & 37.0 & -0.6 & 59.1 & 320 & desirable & desirable & desirable & $\mathrm{C} 2-\mathrm{S} 1$ \\
\hline 49 & 1.4 & 43.6 & 0.5 & 36.2 & -1.0 & 62.9 & 430 & desirable & desirable & desirable & $\mathrm{C} 2-\mathrm{S} 1$ \\
\hline
\end{tabular}

Explanations: $S A R=$ sodium adsorption ratio, $S S P=$ soluble sodium percentage, $K R=$ Kelly's ratio, $M A R=$ magnesium adsorption ratio, $R S C=$ residual sodium carbonate, $P I=$ permeability index, $E C=$ electrical conductivity.

Source: own study. 
from measurement to interpretation, likely affected the results of the USSL classification. Accordingly, the FISs that addressed these issues were an appropriate choice for groundwater quality evaluation.

A comparison between the FIS-based approaches and a deterministic evaluation is presented in Table 3. For samples 8 and 9, SAR, KR, RSC and $E C$ were in the low category, $P I$ was in the high category, $S S P$ was between the moderate and high categories, and $M A R$ was between the low and moderate categories. The USSL diagram classified samples 8 and 9 in the "no risk" C2-S1 class, while the MFL, LFL and SFL models placed them in the "desirable" category. Accordingly, based on both the USSL classification and the FL models, samples 8 and 9 were deemed desirable for irrigation purposes. The FL models classified samples 13 and 14 as "desirable" and samples 16 and 17 as "acceptable", while the USSL classification categorized all four samples as C3-S1. Based on the fuzzy models, samples 19 and 20 were classified as "unacceptable", whereas the USSL classification categorized them as $\mathrm{C} 3-\mathrm{S} 2$ and $\mathrm{C} 4-\mathrm{S} 4$, respectively. For both samples, the SSP and $M A R$ criteria were placed in the low category, $E C$ was in the moderate category, and $P I$ and $K R$ were in the high category. The $S A R$ and $R S C$ were placed in the moderate and high category for sample numbers 19 and 20, respectively. The MFL, LFL and SFL models placed sample 21 in the "desirable", "acceptable" and "acceptable" categories, respectively, while the USSL diagram categorized it as $\mathrm{C} 3-\mathrm{S} 1$. The USSL diagram classified sample 22 as C2$\mathrm{S} 1$ while the FL models placed sample 22 in the "desirable" category.

The developed fuzzy models' superiority over the USSL classification was most apparent in samples of similar quality, as fuzzy models make a more consistent decision, especially with respect to threshold values between two different classes. The results of the MFL method showed that the number of groundwater samples categorized as "desirable", "acceptable" and "unacceptable" were 24, 21 and 4 (Tab. 3). The results obtained from the LFL model were comparable to those of the MFL model. Based on the SFL model, 25, 20 and 4 samples, respectively, were categorized as "desirable", "acceptable" and "unacceptable." Overall, under the USSL classification, the decision-making was based on crisp values, while the FIS drew flexible boundaries using linguistic terms with respect to threshold values between two different classes, thus allowing for more reliable information about groundwater quality. Generally, it can be concluded that the FL models developed in the present study were able to cope with intrinsic uncertainty, were flexible enough to include more criteria or indices compared to traditional classification diagrams, and were able to accommodate human and instrumental errors.

\section{DISCUSSION}

When studying the indices separately, it is easy to classify and understand groundwater quality. However, when different indices are studied together, it becomes difficult to assess overall groundwater quality. The fuzzy inference system (FIS) allows for the derivation of a comprehensive conclusion regarding groundwater quality evolution. There is a good agreement between the fuzzy models and the USSL classification results. It can be concluded that the Mamdani, Sugeno, and Larsen fuzzy logic-based models (MFL, SFL and LFL, respectively) confirmed the USSL classification; beyond confirmation, these models provided a more consistent decision regarding water quality due to the incorporation of various irrigation indices, especially for marginal samples.

The results of the present study confirmed the findings of MIRABBASI et al. [2008], who proposed an irrigation water quality model based on a FIS and compared its performance to that of the USSL diagram. While showing an $84 \%$ agreement with the USSL method, the proposed model proved to be significantly more accurate. Using an adaptive network-based fuzzy inference system (ANFIS), which compared $E C-S A R$ values with the USSL diagram to evaluate irrigation water quality, ALAVI et al. [2010] showed the ANFIS model to be a reliable substitute for the traditional USSL diagram method. Similarly, OSTOVARI et al. [2015] employed a Mamdani FIS with a similar EC$S A R$ and USSL diagram comparison to evaluate groundwater quality, for irrigation purposes, in the Marvdasht alluvial aquifer. The authors showed that in $81 \%$ of cases, the FIS categorized water samples into the same classes as the USSL diagram. Nonetheless, many key groundwater quality criteria (e.g., $P I, K R, M A R, R S C, S S P$ ) were not included. Their accuracy was gauged against a crisp classification method (USSL diagram), and previously reported artificial intelligence techniques (e.g., FL and ANFIS) that based their irrigation water quality evaluations solely on $S A R$ and $E C$, omitting many other criteria important in groundwater quality evaluation and classification.

The exacerbation of soil and water salinization through the intensive use of fertilizers and pesticides, heavy metal pollution, and the use of low-quality water and soil requires the development of new indices and methodologies to address these critical issues. However, while the need for extensive models that consider the effects of water quality on both crops and soil is clear, one must keep in mind that improving a model's suitability by integrating more parameters also increases its uncertainties. There are many driving factors that can affect groundwater quality, including climate, hydrogeology and human activities. The hydrochemical parameters reveal the geological complexity of groundwater, and it was found that water-rock interactions and human activities have the most influence on groundwater quality [GüLER et al. 2012; KOH et al. 2009]. Therefore, FIS is beneficial for groundwater quality evaluation in hydrogeologically complex regions such as the Sarab Plain. It can be argued that the fuzzy inference method is a suitable method for irrigation water quality assessment due to its integrated decision-making mechanism that is based on important irrigation indices. The spatial assessment of groundwater quality of the Sarab Plain using MFL, LFL and SFL models are shown in Figure 10, respectively. As can be seen, samples in the eastern part of the Sarab Plain were categorized as "desirable", and groundwater quality deteriorated in the western and central 
a)



b)

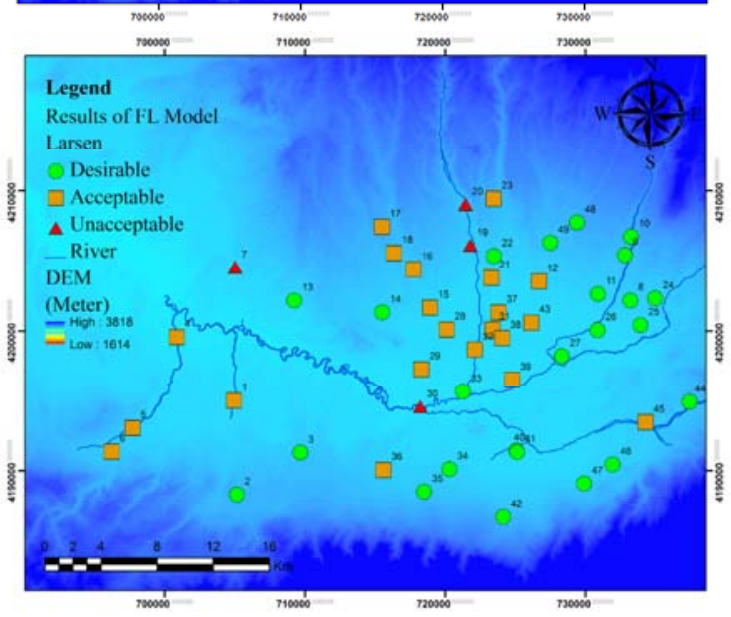

c)



Fig. 10. Spatial assessment of groundwater quality of the Sarab Plain using fuzzy logic models:

a) Mamdani, b) Larsen, c) Sugeno; Source: own study

regions. The results of the present study suggest that, in the study region, the developed FL models developed assess groundwater quality more precisely and with a more consistent logic than the USSL classification diagram (Fig. 8).

\section{CONCLUSIONS}

Due to the inherent uncertainty in water and soil environments, groundwater quality assessment for agricultural use is a challenging task. In the current study, the Mamdani, Larsen and Sugeno fuzzy logic models (MFL, SFL and LFL, respectively) were used to determine water quality more precisely and to manage the inherent uncertainty in the assessment procedure. The present study applied the fuzzy assessment method in groundwater quality evaluation. The assessment of water quality using traditional methods, as well as its classification as "desirable", "acceptable" and "unacceptable" based on water quality standards, were considered less appropriate since such methods overlooked the uncertainty of the sampling, analysis and interpretation steps. Using FL approaches, groundwater quality samples were categorized as "desirable," "acceptable" or "unacceptable" on the basis of expert perception. The results showed that the SFL performed consistently better than the other FL models. The superiority of the developed fuzzy models is most evident in samples of similar quality; FL models produced more consistent results for samples of similar quality compared to the traditional methods. The fuzzy inference method was shown to be suitable for irrigation water-quality assessment because of its integrated decision-making, based on important irrigation indices. In taking uncertainties in measurement and analysis of hydrochemical data into account during model development, the present study introduced a more dependable and flexible method for groundwater quality evaluation compared to traditional methods.

\section{ACKNOWLEDGEMENTS}

The Iranian Ministry of Science, Research, and Technology provided a scholarship to Meysam Vadiati to complete the present study at McGill University. Partial funding for this research was also provided by an NSERC Discovery and Accelerate grant held by Dr. Jan Adamowski at McGill University.

\section{REFERENCES}

ABBASI T., ABBASI S.A. 2012. Water quality indices. Elsevier. ISBN 978-0-444-54304-2 pp. 384.

Alavi N., Nozari V., Mazloumzadeh S. M., Nezamabadi-Pour H. 2010. Irrigation water quality evaluation using adaptive network-based fuzzy inference system. Paddy and Water Environment. Vol. 8. No. 3 p. $259-266$. DOI $10.1007 / \mathrm{s} 10333-$ 010-0206-6.

Alizadeh A., Keshavarz A. 2005. Status of agricultural water use in Iran. In: Water conservation, reuse, and recycling. Proceedings of an Iranian-American workshop. Washington DC, USA. National Academies Press p. 94-105.

APHA, AWEF 1998. Standard methods for the examination of water and wastewater. Washington, DC. American Public Health Association, American Water Works Association, and Water Environment Federation pp. 26.

Asadollahfardi G., Taklify A., Ghanbari A. 2011. Application of artificial neural network to predict TDS in Talkheh Rud River. Journal of Irrigation and Drainage Engineering. Vol. 138. No. 4 p. 363-370. DOI 10.1061/(ASCE)IR.19434774.0000402 .

BAIN R.E.S., Wright J.A., Christenson E., BARTRAM J.K. 2014. Rural: urban inequalities in post 2015 targets and indicators for drinking-water. Science of the Total Environment. No. 490 p. 509-513. DOI 10.1016/j.scitotenv.2014.05.007.

Bardossy A., Bronstert A., Merz B. 1995. 1-, 2-and 3-dimensional modeling of water movement in the unsaturated soil matrix using a fuzzy approach. Advances in Water Resources. Vol. 18. No. 4 p. 237-251. DOI 10.1016/0309-1708(95) 00009-8. 
Barua A., Mudunuri L.S., Kosheleva O. 2013. Why trapezoidal and triangular membership functions work so well: Towards a theoretical explanation. University of Texas at El Paso DigitalCommons@UTEP Departmental Technical Reports (CS). Paper 783.

DahiYa S., Singh B., Gaur S., Garg V.K., Kushwaha H.S. 2007. Analysis of groundwater quality using fuzzy synthetic evaluation. Journal of Hazardous Materials. Vol. 147. No. 3 p. 938-946. DOI 10.1016/j.jhazmat. 2007.01.119.

DANGE P.S., LAD R.K. 2017. A fuzzy rule based system for an environmental acceptability of Sewage Treatment Plant. KSCE Journal of Civil Engineering, Vol. 21. Iss. 7 p. 2590 2595.

DONEEN L.D. 1962. The influence of crop and soil on percolating water. In: Proceedings of the 1961 Biennial conference on Groundwater recharge p. 156-163.

EATON F.M. 1950. Significance of carbonates in irrigation waters. Soil Science. Vol. 69. Iss. 2 p. 123-134.

Goethals P., VOLK M. 2016. Implementing sustainability in water management: Are we still dancing in the dark? Sustainability of Water Quality and Ecology. Vol. 7 p. 1-4.

GorgiJ D., VADIATI M. 2014. Determination of groundwater quality based on important irrigation indices using analytical hierarchy process method. Agricultural Advances. Vol. 3. Iss. 6 p. 176-185. DOI 10.14196/aa.v3i6.1425.

GowD S.S. 2005. Assessment of groundwater quality for drinking and irrigation purposes: A case study of Peddavanka watershed, Anantapur District, Andhra Pradesh, India. Environmental Geology. Vol. 48. Iss. 6 p. 702-712. DOI 10.1007/s00254-005-0009-z.

Güler C., Kurt M.A., Alpaslan M., Kbulut C. 2012. Assessment of the impact of anthropogenic activities on the groundwater hydrology and chemistry in Tarsus coastal plain (Mersin, SE Turkey) using fuzzy clustering, multivariate statistics and GIS techniques. Journal of Hydrology. Vol. 414 p. 435451. DOI 10.1016/j.jhydrol.2011.11.021.

Hellendoorn H., ThOMAS C. 1993. Defuzzification in fuzzy controllers. Journal of Intelligent and Fuzzy Systems. Vol. 1. Iss. 2 p. 109-123. DOI 10.3233/IFS-1993-1202.

Hosseini-Moghari S.M., Ebrahimi K., Azarnivand A. 2015. Groundwater quality assessment with respect to fuzzy water quality index (FWQI): An application of expert systems in environmental monitoring. Environmental Earth Sciences. Vol. 74. Iss. 10 p. 7229-7238. DOI $10.1007 / \mathrm{s} 12665-015-$ 4703-1.

HowARI F.M., Yousef A.R., RAFIE S. 2005. Hydrochemical analyses and evaluation of groundwater resources of North Jordan. Water Resources. Vol. 32. Iss. 5 p. 555-564. DOI 10.1007/s11268-005-0071-7.

Kelley W.P. 1940. Permissible composition and concentration of irrigation water. In Proceedings of the American Society of Civil Engineers. Vol. 66. p. 607-613.

Koh D.C., Chae G.T., Yoon Y.Y., Kang B.R., KoH G.W., Park K.H. 2009. Baseline geochemical characteristics of groundwater in the mountainous area of Jeju Island, South Korea: Implications for degree of mineralization and nitrate contamination. Journal of Hydrology. Vol. 376. No. 1 p. 81-93. DOI 10.1016/j.jhydrol.2009.07.016.

KusKo B. 1993. Fuzzy thinking: The new science of fuzzy logic. New York. Hyperion. ISBN 1562828398 pp. 318.

LARSEN P.M. 1980. Industrial applications of fuzzy logic control. International Journal of Man-Machine Studies. Vol. 12. No. 1 p. 3-10.

Lermontov A., Yokoyama L., LeRmontov M., Machado M.A.S. 2009. River quality analysis using fuzzy water quality index: Ribeira do Iguape river watershed, Brazil. Ecological
Indicators. Vol. 9. No. 6 p. 1188-1197. DOI 10.1016/ j.ecolind.2009.02.006

MAMDANi E.H., AssiLIAN S. 1975. An experiment in linguistic synthesis with a fuzzy logic controller. International Journal of Man-Machine Studies. Vol. 7. Iss. 1 p. 1-13.

Marghade D., MalPe D.B., Zade A.B. 2011. Geochemical characterization of groundwater from northeastern part of Nagpur urban, Central India. Environmental Earth Sciences. Vol. 62. No. 7 p. 1419-1430. DOI 10.1007/s12665-010-0627-y.

MathWorks 2014. MATLAB and Fuzzy Logic Toolbox. Release 2014a. MathWorks Natick, Massachusetts.

Michael A.M. 2008. Irrigation: theory and practice. 2nd ed. Vikas Publishing House Pvt Ltd, New Delhi. ISBN 8125918671 pp. 1857.

Mirabbasi R., Mazloumzadeh S.M., Rahnama M.B. 2008. Evaluation of irrigation water quality using fuzzy logic. Research Journal of Environmental Sciences. Vol. 2. No. 5 p. $340-352$.

Ostovari Y., Beigi-Harchegani H., Asgari K. 2015. A fuzzy logic approach for assessment and mapping of groundwater irrigation quality: A case study of Marvdasht aquifer, Iran. Archives of Agronomy and Soil Science. Vol. 61. No. 5 p. 711-723. DOI 10.1080/03650340.2014.946020.

PALIWAL K.V. 1972. Irrigation with saline water. $2^{\text {nd }}$ ed. IARI, New Delhi pp. 198.

PIPER A.M. 1944. A graphic procedure in the geochemical interpretation of water-analyses. Eos, Transactions American Geophysical Union. Vol. 25. No. 6 p. 914-928.

RAGHUNATH H.M. 1987. Groundwater. $2^{\text {nd }}$ ed. Wiley Eastern, New Delhi. ISBN 0852162981 pp. 563.

RAMESH K., ElANGO L. 2012. Groundwater quality and its suitability for domestic and agricultural use in Tondiar river basin, Tamil Nadu, India. Environmental Monitoring and Assessment. Vol. 184. No. 6 p. 3887-3899. DOI 10.1007/s10661011-2231.

Ross T.J. 2012. Fuzzy logic with engineering applications. $3^{\text {rd }}$ ed. New York. Wiley. ISBN 978-0-470-74376-8 pp. 585.

SCHOELLER H. 1962. Les eaux souterraines : hydrologie dynamique et chimique; recherché, exploitation et évaluation des resources [Groundwater: dynamic and chemical hydrology; research, exploitation and evaluation of resources]. Vol. 1. Paris. Masson et $\mathrm{C}^{\mathrm{ie}}$ pp. 642.

Singh S.K., SRIVAstava P.K., PAndey A.C., Gautam S.K. 2013. Integrated assessment of groundwater influenced by a confluence river system: concurrence with remote sensing and geochemical modelling. Water Resources Management. Vol. 27. No 12 p. 4291-4313. DOI 10.1007/s11269-013-0408-y.

STIFF Jr. H.A. 1951. The interpretation of chemical water analysis by means of patterns. Journal of Petroleum Technology. Vol. 3. No. 10 p. $15-17$. DOI 10.2118/951376-G.

SuAREZ D.L., WoOD J.D., LeSCH S.M. 2006. Effect of SAR on water infiltration under a sequential rain-irrigation management system. Agricultural Water Management. Vol. 86. No. 1 p. 150-164. DOI 10.1016/j.agwat.2006.07.010.

TAKagi T., Sugeno M. 1985. Fuzzy identification of systems and its applications to modeling and control. IEEE Transactions on Systems, Man, and Cybernetics. Vol. 15. No. 1 p. 116132. DOI 10.1109/TSMC.1985.6313399.

USSL 1954. Diagnosis and improvement of saline and alkali soils. U.S. Salinity Laboratory Staff. U.S. Department of Agriculture Handbook No. 60.

VADIATI M., ADAMOWSKI J., BEYNAGHI A. 2018. A brief overview of trends in groundwater research: Progress towards sustainability? Journal of Environmental Management. Vol. 223 p. 849-851. DOI 10.1016/j.jenvman.2018.06.086.

VAdiati M., Asghari-Moghaddam A., NAKHaEI M., AdAMOWSKI J., AKBARZADEH A.H. 2016. A fuzzy-logic based de- 
cision-making approach for identification of groundwater quality based on groundwater quality indices. Journal of Environmental Management. Vol. 184 p. 255-270. DOI 10.1016/j.jenvman.2016.09.082

Vadiati M., Nakhaei M., Amiri A. V., Mirarabi A. 2013. An assessment of the Karoon river's water quality using the fuzzy inference model. Water Engineering. Vol. 6. No. 3 p. 39-48.

van der Gun J., Haie N., HiRata R., Lopez-GunN E., Neupane B., Shah T., Wallin B. 2007. Groundwater resources sustainability indicators. first ed. UNESCO, Paris.

Wang D., LiU D., Ding H., Singh V. P., WANG Y., Zeng X., ... WANG L. 2016. A cloud model-based approach for water quality assessment. Environmental Research. Vol. 148 p. 24 35.

WANG W.C., Xu D.M., Chau K.W., LeI G.J. 2014. Assessment of river water quality based on theory of variable fuzzy sets and fuzzy binary comparison method. Water Resources Management. Vol. 28. No. 12 p. 4183.

WANG X., RuAn D., KeRRE E.E. 2009. Mathematics of fuzzinessbasic issues. Studies in Fuzziness and Soft Computing. Vol. 245. Berlin/Heidelberg. Springer pp. 220. DOI 10.1007/9783-540-78311-4.

WiLCOX L. 1955. Classification and use of irrigation waters. Washington, DC. USDA. Circular. No. 969 pp. 19.

ZADEH L.A. 1965. Fuzzy sets. Information and Control. Vol. 8. No. 3 p. 338-353. DOI 10.1016/S0019-9958(65)90241-X.

\section{Meysam VADIATI, Deasy NALLEY, Jan ADAMOWSKI, Mohammad NAKHAEI, Asghar ASGHARI-MOGHADDAM}

\section{Analiza porównawcza modeli opartych na logice rozmytej do oceny jakości wód podziemnych na podstawie wskaźników nawadniania}

\section{STRESZCZENIE}

Modelowanie jakości wód podziemnych odgrywa ważną rolę w procesach podejmowania decyzji dotyczących zarządzania zasobami wodnymi. W związku z tym należy opracować modele uwzględniające naturalną niepewność, która pojawia się od etapu pomiaru próbki, aż do interpretacji danych. Wykazano, że modele sztucznej inteligencji, w szczególności systemy wnioskowania rozmytego (FIS), są skuteczne w ocenie jakości wód podziemnych w odniesieniu do złożonych warstw wodonośnych. Zastosowanie teorii zbiorów rozmytych do podejmowania decyzji związanych z jakością wód podziemnych w kontekście produkcji rolnej, modele oparte na logice rozmytej Mamdaniego, Sugeno i Larsena (odpowiednio MFL, SFL i LFL) zostały wykorzystane do opracowania serii nowych, uogólnionych modeli, opartych na regułach rozmytych, do oceny jakości wody z wykorzystaniem powszechnie akceptowanych wskaźników nawadniania. Zamiast czerpać z jakościowych parametrów fizykochemicznych wód gruntowych, w niniejszym badaniu zastosowano powszechnie przyjęte wskaźniki rolne (np. kryteria nawadniania) podczas opracowywania modeli jakości wód podziemnych MFL, SFL i LFL. Za pomocą tych nowo opracowanych modeli, wygenerowano znacznie bardziej spójne wyniki niż z zastosowaniem diagramu Amerykańskiego Laboratorium Gleby (USSL), uwzględniono nieodłączną niepewność danych progowych. Modele te były skuteczne w ocenie jakości wód podziemnych do zastosowań rolniczych. Model SFL jest zalecany, ponieważ miał najlepszą efektywność pod względem dokładności w ocenie jakości wód podziemnych z użyciem wskaźników nawadniania.

Słowa kluczowe: model Larsona, model Mamdaniego, model Sugeno, model wnioskowania rozmytego, reguly rozmyte, równanie Saraba, wskaźniki irygacyjne 